\title{
A Stroke Mimic: Post-stroke Recrudescence Syndrome Triggered by Ramsay Hunt Syndrome
}

\author{
Bir Inme Taklitçisi; Ramsay Hunt Sendromu ile Tetiklenen İnme Sonrası \\ Yeniden Kötüleşme Sendromu
}

\author{
University of Health Sciences Turkey, Bagcilar Training and Research Hospital, Clinic of Neurology, Istanbul, Turkey
}

\begin{abstract}
On evaluating patients referring to emergency departments with stroke symptoms, many non-vascular causes are seen as the responsible etiologies. To identify stroke mimics, patients undergo physical and neurological examination, and neuroimaging. Hereby, we aimed to raise awareness of post-stroke recrudescence syndrome (PRS), a rare stroke mimic. PRS is a stroke mimic, especially that triggered by infections. Considering this syndrome is important to avoid unnecessary diagnostic tests and treatments.
\end{abstract}

Keywords: Stroke, mimic, recrudescence syndrome, infection

\section{Öz}

İnme semptomları ile acile başvuran hastalar değerlendirildiğinde, çok sayıda vasküler dışı hastalık süreçlerinin de inme benzeri bir tabloya yol açabileceği görülmektedir. Bu gibi inme taklitçilerinin tanınması amacıyla hastanın hikaye, fizik muayene, laboratuvar ve görüntüleme yöntemleri ile dikkatli değerlendirilmesi gereklidir. Biz, hastamız ile inme taklitçilerinden biri olan ve nadir bilindiğini düşündügümüz post-stroke recrudescence sendromunu (PRS) sunarak bu konuda farkındalık yaratmayı amaçladık. PRS enfeksiyon başta olmak üzere çeşitli nedenlerle tetiklenen bir inme taklitçisidir. Bu gibi inme taklitçilerinin tanınması hastanın gereksiz inme tedavisinden ve buna bağlı gelişebilecek komplikasyonlardan korunmasını sağlayacaktır.

Anahtar Kelimeler: İnme, taklitçi, recrudescence sendromu, enfeksiyon

\section{Introduction}

On evaluating patients presenting to the emergency department with stroke symptoms, non-vascular diseases are often seen as the cause of stroke symptoms. These situations, which we define as stroke mimics, can cause diagnostic difficulties and are often difficult to distinguish from real stroke. Many nonvascular causes mimic a stroke: seizures, migraine, toxic metabolic conditions, peripheral neuropathies, and degenerative neurological diseases are a few of them.

Post-stroke recrudescence syndrome (PRS) is a rare syndrome, defined as a temporary worsening of post-stroke sequela findings or deficits associated with a previous stroke, which can mimic a stroke. Systemic infections and use of sedative drugs or anesthetic agents can cause PRS (1). In this case report, we aimed to raise awareness of this issue by presenting PRS, a rare stroke mimic.

\section{Case Report}

A70-year-old female patient was admitted to our emergency neurology outpatient clinic. She had pain radiating to her left ear three months before admission. Moreover, she had red fluid-filled rashes in the painful areas, was diagnosed with shingles, and was started on acyclovir $750 \mathrm{mg} /$ day (Figure 1).

The patient was diagnosed with diabetes, hypertension, and hyperlipidemia. Six years ago, due to abduction deficit in her right eye she was hospitalized in a state hospital and was diagnosed with diabetic cranial neuropathy. Two years ago, she complained of

Address for Correspondence/Yazışma Adresi: Eda Çoban Assoc. Prof. MD, University of Health Sciences Turkey, Bagcilar Training and Research Hospital, Clinic of Neurology, Istanbul, Turkey

Phone: +90 5054834377 E-mail: eda_coban@yahoo.com ORCID: orcid.org/0000-0001-5894-7318

Received/Geliş Tarihi: 16.06.2020 Accepted/Kabul Tarihi: 21.01.2021

${ }^{\circ}$ Copyright 2021 by Turkish Neurological Society

Turkish Journal of Neurology published by Galenos Publishing House. 
imbalance and walking difficulty, which developed acutely with high blood pressure and lasted for one month.

It was stated that, on examining the patient, no neurological pathology was found during this period, and her complaints resolved spontaneously within one month. The patient received acetylsalicylic acid, clopidogrel, insulin, and antihypertensive, oral antidiabetic, and antilipidemic treatments. She was diagnosed with Ramsay Hunt syndrome (RHS) due to inability to control facial muscles and close the eyes, which developed two weeks after the rash on her face. She was started on $3000 \mathrm{mg} /$ day valacyclovir, $1 \mathrm{mg} / \mathrm{kg} /$ day oral prednisolone, $2400 \mathrm{mg} /$ day gabapentin, and vitamin B complex.

The patient presented to our emergency department with imbalance in walking and facial paralysis. On her neurological examination, her left nasolabial sulcus was faint, she was unable to raise her left eyebrow, her left eye blink was weak, and her gait was ataxic (Figure 2). On her systemic examination, erythematous, painful, vesicular eruptions and occasional crusts were detected on the left side the neck (scalp, behind the ear, under the chin, zygomatic bone, and areas that fit C2-C3 dermatome). No acute lesions were detected on diffusion-weighted magnetic resonance imaging (MRI) of the patient, which was performed twice. T2weighted MRI revealed numerous chronic periventricular ischemic lesions and chronic infarction in the right half of the pons (Figure $3,4)$. The patient's current treatments were maintained, and she was followed up. After one month of receiving antiviral therapy and corticosteroid therapy, all symptoms regressed.

\section{Discussion}

RHS, which is also known as herpes zoster oticus, is a disease characterized by severe ear pain, vesicles around the auricle, peripheral facial paralysis, and vestibulocochlear dysfunction. It occurs due to the reactivation of the virus and infection of the geniculate ganglion due to reasons such as diabetes mellitus, hypertension, use of immunosuppressive drugs, and old age (2). Our patient had the following predisposing factors for PRS: older age, diabetes and hypertension, and acute stress factors. The

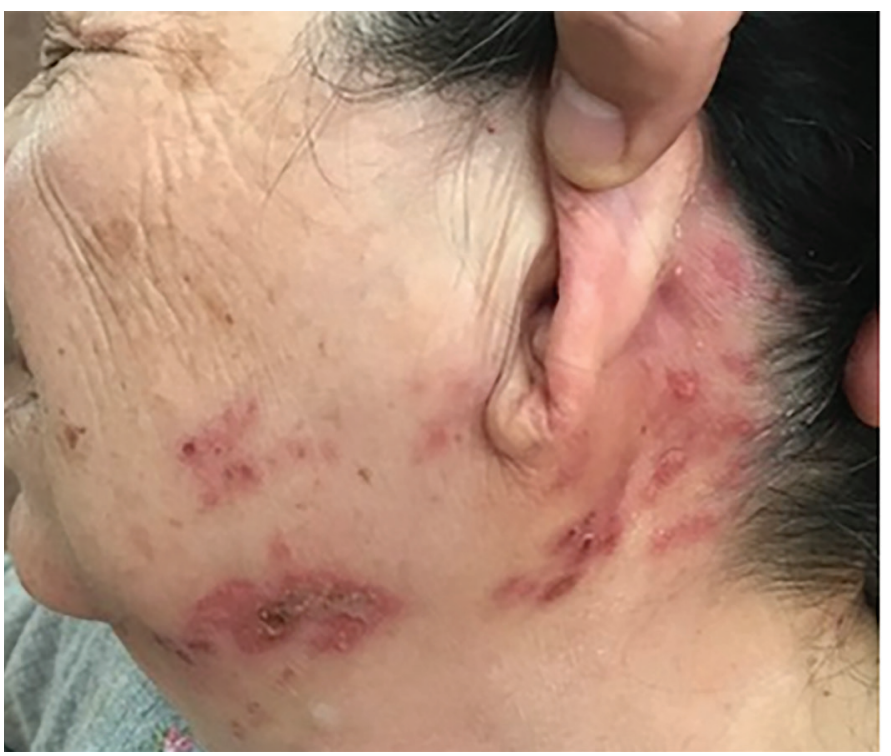

Figure 1. Vesicular rash on the left side of the neck development of imbalance under antiviral, steroid, and vitamin B treatments suggested a possible acute stroke due to the existing risk factors. However, based on a series of MRI examinations, the central pathology was excluded.

In fact, temporary stroke symptoms are common in patients with stroke. Unfortunately, it is impossible to differentiate PRS from a new stroke with only clinical findings.

PRS is defined as the temporary worsening of sequela findings after stroke or deficits associated with a previous stroke. The triggers of the syndrome are known as infection, hypotension and hyponatremia, insomnia, stress, and anesthetic agent use. Female gender, African American race, diabetes, dyslipidemia, and smoking are considered risk factors (3).

A study examined 340 patients with transient neurological attacks and categorized the patients as having transient ischemic attack (TIA), PRS, or other causes. PRS was detected in $10 \%$ of the patients. On examining the characteristics and risk factors in all patients, there were similar vascular risk factors in patients with TIA and those with PRS. However, the presence of more than one acute stressor in the PRS group was statistically significant (4). Therefore, the distinction between a true stroke and PRS is difficult due to similar risk factors and recurrent neurological findings. PRS diagnostic criteria have been defined as follows: 1) Temporary worsening of residual focal neurological findings after stroke; 2) signs of chronic stroke on brain imaging; 3) no acute lesions detected on diffusion-weighted MRI; 4) cerebral ischemia considered unlikely (e.g., symptom duration greater than one hour without new diffusion-weighted MRI lesion; no suspicion for low-flow TIA from cerebral artery stenosis or occlusion); 5) exclusion of seizures, clinically or electroencephalographically (1). The mechanism that causes PRS is not clearly known. The most comprehensive study on this subject in the literature is the work of Topçuoğlu et al. (1). In their study, it was emphasized that previous infarcts caused a tendency to infections, and successive infections resulted in the development of the syndrome through cytokinemediated ways. Similarly, the effect of fluid and electrolyte imbalance on neuronal excitability and conduction along white

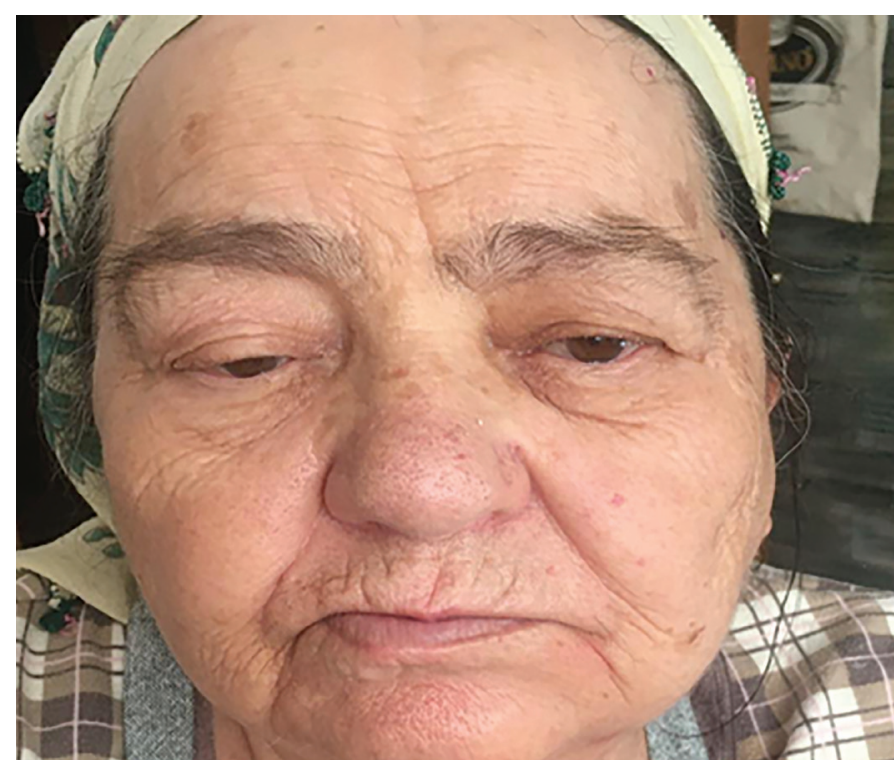

Figure 2. Bell's palsy 
matter pathways is known. This explains that hyponatremia is among the triggers of the syndrome (1).

The first studies on PRS were performed using anesthetic agents. Due to the complexity of neural networks containing opioid-dependent receptors, effective in neural plasticity, this syndrome develops. The glutamate-dependent $\mathrm{N}$ methyl $\mathrm{D}$ aspartate (NMDA) and $\alpha$-amino-3-hydroxy-5-methyl-4-isoxazole propionic acid (AMPA) receptors, involved in these networks and responsible for both neurogenesis and synaptogenesis, are known to be effective in forming perilesional compensatory networks
$(5,6,7)$. However, opioid-dependent mu receptors interact with them and destabilize compensatory neuroplasticity. It performs this function by inhibiting the release of presynaptic glutamate, substance P, and neurokinin $(8,9)$. In fact, Bernstock et al. (10) showed that PRS developed in their patients after administration of hydromorphone, used for pain control, which proves the reactivation of sequela findings due to the interaction between opioid analgesics and NMDA/AMPA receptor transmission.

Similar to our case report, PRS after infection is also reported in the literature. Qureshi (11) reported an 82-year-old patient
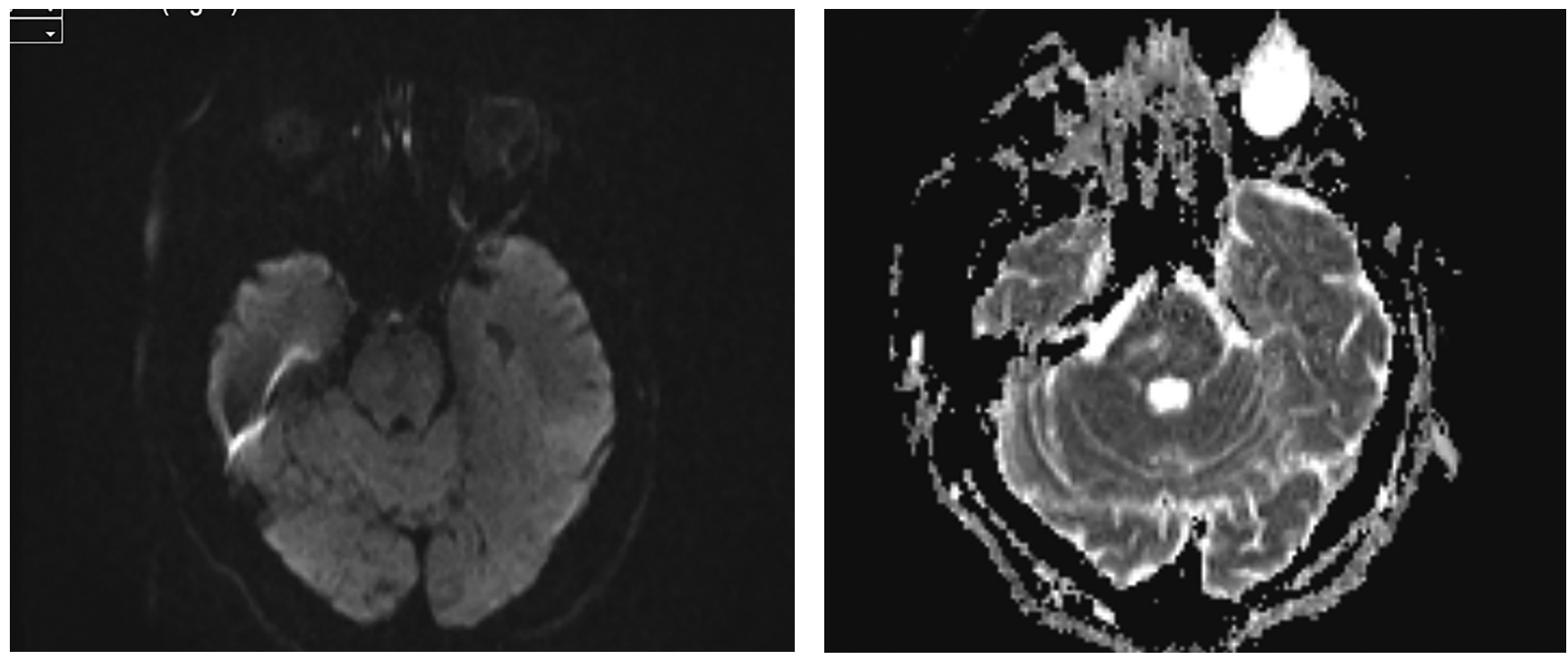

Figure 3. Normal diffusion-weighted magnetic resonance imaging of the brain
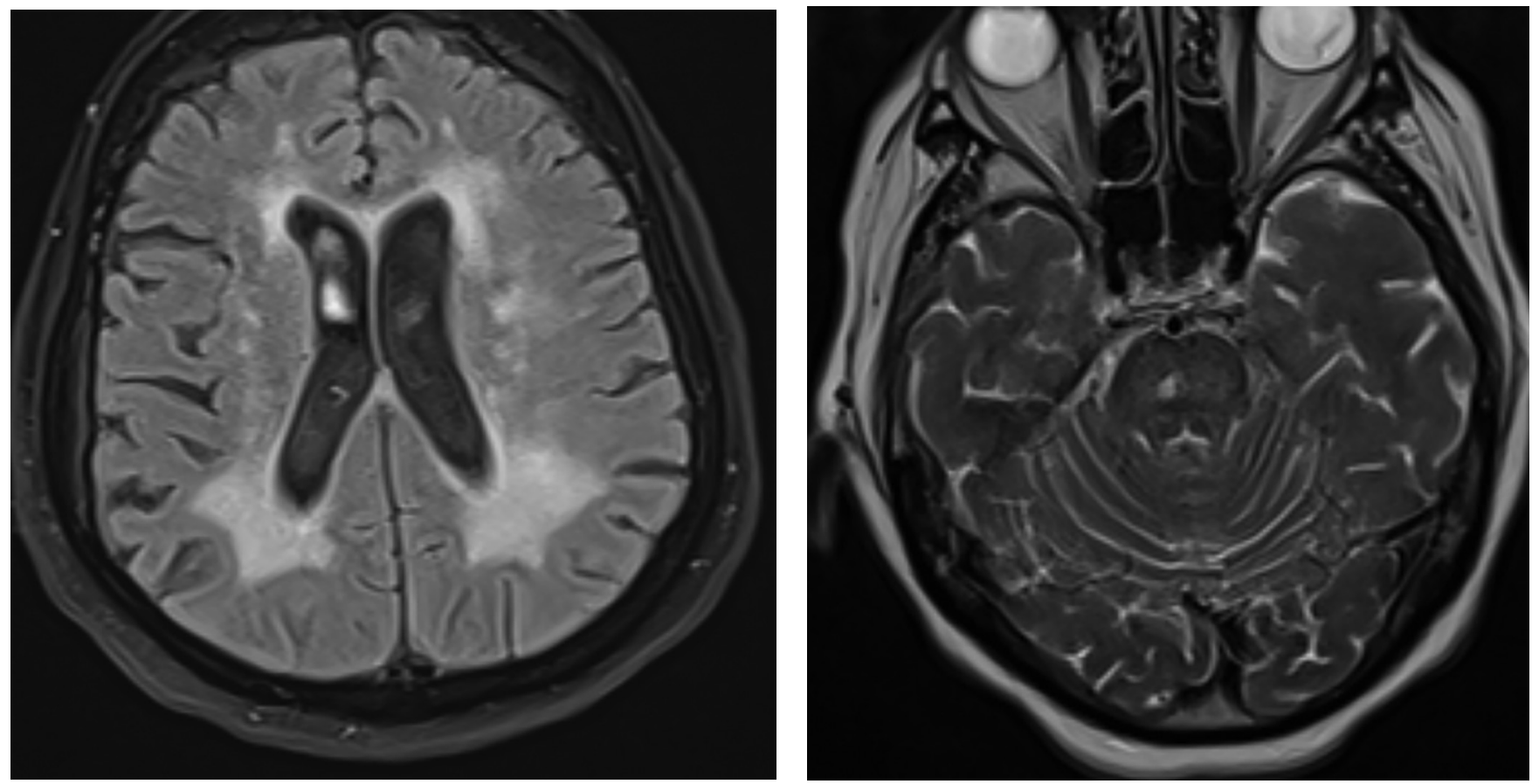

Figure 4. Magnetic resonance imaging of the brain demostrating chronic ischemic changes, fluid-attenuated inversion recovery (FLAIR) and T2-weighted sequences. 
presenting with recurrent cerebellar findings after urinary tract infection, who had a stroke 28 years ago. Chronic lesions of the patient's left parietal lobe, cerebellum, and thalamus were detected on MRI, while no acute lesions were detected. After treatment of the urinary tract infection, all symptoms regressed.

Six years ago, our patient was followed up due to diabetic cranial neuropathy. Two years ago, she experienced imbalance and walking difficulty triggered by a hypertensive crisis. No acute infarction was detected and only chronic pons infarction and chronic periventricular ischemic changes were detected during that period. Chronic pons infarction may be the lesion responsible for the clinical findings six years ago. Imaging performed during that period could not be obtained. Because the patient experienced a similar clinical status triggered by RHS and similar spontaneous regression for the second time, we suspected PRS. Spinal cord involvement, which might be another cause of ataxia, was not considered because of recurrent similar clinical status and absence of accompanying cord findings. Although no cervical imaging was performed, no signal change was detected in the C2-3 spinal cord on sagittal cranial MRI images.

As a result, PRS is one of the lesser known, but believed to be frequent, stroke mimic. PRS should be considered, among other known mimics, in objectively recurrent or worsening neurological pictures. Recognition of PRS developing due to certain triggers, especially infections and electrolyte and metabolic disorders, will eliminate unnecessary diagnostic and treatment approaches. Treatment of the triggering factor will be sufficient to treat the patient.

\section{Ethics}

Informed Consent: Written informed consent was obtained from the patient.
Peer-review: Externally peer-reviewed.

Financial Disclosure: The author declared that this study received no financial support.

\section{References}

1. Topçuoğlu MA, Saka E, Silverman SB, et al. Recrudescence of deficits after stroke, clinical and imaging phenotype, triggers, and risk factors. JAMA Neurol 2017;74:1048-1055.

2. Whitley RJ. A 70-year-old woman with shingles: review of herpes zoster. JAMA 2009;302:73-80.

3. Owens $\mathrm{S}$. New study identifies features, triggers, and risk factors for poststroke recrudescence. Neurology Today 2017 August. Available from https://journals.lww.com/neurotodayonline/blog/breakingnews Accessed date: 30.01 .2020

4. Jun-O'connell A, Henninger N, Moonis N. Recrudescence of old stroke deficits among transient neurological attacks. Neurohospitalist 2019;9:183189.

5. Waldhoer M, Bartlett SE, Whistler JL. Opioid receptors. Annu Rev Biochem 2004;73:953-990.

6. Dacher M, Nugent FS. Opiates and plasticity. Neuropharmacology 2011;61:1088-1096.

7. Lamprecht R LeDoux J. Structural plasticity and memory. Nat Rev Neurosci 2004;5:45-54.

8. Ostermeier AM, Schlosser B, Schwender D, Sutor B. Activation of muand delta-opioid receptors causes presynaptic inhibition of glutamatergic excitation in neocortical neurons. Anesthesiology 2000;93:1053-1063.

9. Yu Y, Zeng C, Shu S, et al. Similar effects of substance P on learning and memory function between hippocampus and striatal marginal division. Neural Regen Res 2014;9:857-863.

10. Bernstock JD, Budinich CS, Cohen LG. Recrudescence of focal Stroke Symptoms During Pain Management with Hydromorphon. Front Neurol 2016;7:50.

11. Qureshi MIA. Neurological decompensation of an old ischaemic stroke following infection. J Clin Cases Rep 2019;2:28-34. 